\title{
UPAYA MENYISIPKAN PESAN MORAL DALAM MATERI STATISTIKA
}

\author{
Retno Subekti \\ Jurusan Pendidikan Matematika FMIPA UNY \\ retnosubekti@uny.ac.id
}

\begin{abstract}
ABSTRAK
Seorang pengajar pasti berharap kelak peserta didiknya akan menjadi pribadi yang cemerlang dalam sisi akademis, sukses dalam karier serta jujur dalam setiap tindakannya. Dalam makalah ini penulis sebagai dosen statistika memaparkan upaya-upaya menyisipkan pesan moral dalam perkuliahan statistika agar dapat menjembatani pengajar statistika untuk menyisipkan beberapa pendidikan moral kepada mahasiswa. Beberapa topik dalam statistika seperti pemilihan teknik sampel yang sesuai, bagaimana menyikapi adanya outliers ternyata mempunyai pesan-pesan moral yang dapat disisipkan saat penyampaian materi kepada peserta didik/mahasiswa.
\end{abstract}

Kata Kunci : Pesan moral, Jujur, Statistika, Outliers, Sampel

\begin{abstract}
Every lecturer absolutely hope the students will become a person who brilliantly in the academic side, success in career and honest in every action. In this paper the authors as a statistics lecturer describe the efforts to insert a moral message in statistics class in order to bridge the lecturer for inserting some moral topic to the students. Some topics in statistics such as the selection of appropriate sampling techniques, how to respond to the outliers apparently has moral messages that can be inserted in lesson to the students.
\end{abstract}

Keywords : Moral, Honest, Statistics, Outliers, Samples

\section{Pendahuluan}

Apakah saudara pernah mendengar tentang suatu tulisan yang berjudul How to Lie with Statistics? Mungkin saudara pernah mendengarnya untuk sebagian besar orang yang sering menjelajah literatur yang berkaitan dengan statistika. Ada sebuah buku yang berjudul How to Lie with Statistics karangan Darrel Huff, 1954. Mungkin bisa terbersit kesan yang tidak baik dari statistik. Atau mungkin saudara pernah membaca tulisan tentang data-data yang dikeluarkan oleh suatu badan statistika yang mungkin dipertanyakan validitasnya dan kasus yang seringkali dijumpai juga adalah bagaimana saat segelintir mahasiswa yang berjuang menulis tugas akhir agar bisa lulus tetapi dengan menyalahgunakan data atau memanipulasi data sehingga hasil yang diperolehnya sesuai dengan harapannya. 
Tentunya hal-hal demikian bisa menjadi perhatian pada pengajar agar senantiasa tidak lupa untuk menyisipkan pesan moral dan kebaikan kepada mahasiswa. Sebagai pengajar di jurusan pendidikan matematika FMIPA UNY khususnya di bidang statistika, usahausaha untuk menyisipkan pesan-pesan moral saat perkuliahan statistika menjadi sangat penting agar mahasiswa mendapatkan pengalaman menarik terkait materi. Banyak cara yang mungkin telah dipaparkan oleh sebagian besar artikel mengenai pendidikan karakter dan pembelajaran. Pemberian contoh ilustrasi yang baik jika digunakan metode pembelajaran kontekstual atau menanamkan karakter yang baik seperti sikap mandiri, bekerja sama dengan menggunakan metode pembelajaran. Hal ini sesuai dengan pernyataan bahwa implementasi berbagai model pembelajaran dalam pembelajaran Matematika dapat memfasilitasi pembentukan karaketr peserta didik dalam Endang L (2012).

Oleh karena itu seperti harapan semua pengajar untuk dapat menanamkan hal-hal kebaikan dalam perkuliahan, penulis ingin turut berbagi pengalaman mengenai bagaimana menyisipkan pesan moral dari beberapa matakuliah dalam topik statistika. Sesuai dengan bidang ilmu yang ditekuni yaitu statistika terapan, dalam makalah ini akan dipaparkan materi statistika dan pesan moral yang bersesuaian agar dapat menjembatani pengajar statistika untuk menyisipkan beberapa pendidikan moral kepada mahasiswa.

Pengajar dalam hal ini siapapun pasti berharap kelak mahasiswa akan menjadi pribadi yang cemerlang dalam sisi akademis, sukses dalam karier serta jujur dalam setiap tindakannya. Sehingga harapan penulis, mahasiswa yang mempelajari Statistika, bukan berarti mereka akan belajar berbohong di kemudian hari agar dapat sukses melainkan mahasiswa dapat mengambil sisi positif dalam perkuliahan disamping topik materinya adalah dasar untuk mendukung proses penelitiannya.

\section{Pembahasan}

Mendengar kata statistika, mungkin akan terbayang sekian banyak hal, dua diantaranya adalah data dan analisis dalam penelitian. Statistik dan data adalah suatu pasangan kata yang tidak mungkin dipisahkan, sering dijumpai dalam banyak hal seperti record banyak gol yang dicetak oleh seorang pesepakbola mungkin sudah tidak asing lagi bagi pecinta bola. Ataupun Badan Pusat Statistika (BPS) yang identik berbagai macam data yang mewakili tentang suatu negara. Statistika identik dengan penelitian, seperti bagaimana menyajikan data, memberikan informasi bahkan sampai pada menarik kesimpulan 
setelah melewati serangkaian uji hipotesis.

\section{Pembelajaran Statistika dalam perkuliahan}

Ilmu statistika mulai dikenal dan dipelajari secara khusus saat masuk ke jenjang Perguruan Tinggi walaupun siswa sekolah menengah sudah mempelajari dasar-dasar Statistika. Hampir semua jurusan maupun program studi mengenal ilmu Statistika. Bisa jadi mahasiswa mengambil sebuah matakuliah yang bernama Statistika atau mempelajari analisis/metode-metode statistika dalam perkuliahan Metode Penelitian yang sering disingkat menjadi matakuliah Metopen. Pembelajaran Statistika dalam perguruan tinggi umumnya dijumpai pada dua semester yaitu Statistika I yang berisi tentang pengertian Statistika, statistika deskriptif, hingga inferensi untuk pengujian rata-rata populasi dan Statistika II yang berisi pengenalan beberapa analisis statistika lanjut.

Pesan-pesan moral yang dibahas seperti yang diketahui secara umum, adalah pesan-pesan kebaikan seperti sikap jujur, peduli dengan sesama dan sekitarnya, peduli lingkungan dan lain lain. Sebagaimana aspek-aspek yang terangkum dalam materi pendidikan karakter yang disusun oleh badan penelitian dan pengembangan, pusat kurikulum kementrian pendidikan nasional (2011:10) sebagai berikut :

1. Religius, sikap dan perilaku yang patuh dalam melaksanakan ajaran agama yang dianutnya, toleran terhadap pelaksanaan ibadah agama lain, serta hidup rukun dengan pemeluk agama lain

2. Jujur, perilaku yang didasarkan pada upaya menjadikan dirinya sebagai orang yang selalu dapat dipercaya dalam perkataan, tindakan dan pekerjaan

3. Toleransi, sikap dan tindakan yang menghargai perbedaan agama, suku, etnis, pendapat, sikap, dan tindakan orang lain yang berbeda dari dirinya

4. Displin, tindakan yang menunjukkan perilaku tertib dan patuh pada berbagai ketentuan dan peraturan

5. Kerja keras, tindakan yang menunjukkan upaya sungguhsungguh dalam mengatasi berbagai hambatan dan tugas, serta menyelesaikan tugas sebaik-baiknya

6. Kreatif, berpikir dan melakukan sesuatu untuk menghasilkna cara atau hasil baru dari sesuatu yang telah dimilikinya.

7. Mandiri, sikap dan perilaku yang tidak mudah tergantung pada orang lain dalam menyelesaikan tugastugas

8. Demokratis, cara berfikir, bersikap dan bertindak yang menilai sama hak dan kewajiban dirinya dan orang lain 
9. Rasa ingin tahu, sikap dan tindakan yang selalu berupaya untuk mengetahui lebih mendalam dan meluas dari sesuatu yang dipelajarinya, dilihat dan didengar

10. Semangat kebangsaan, cara berpikir, bersikap dan berwawasan yang menempatkan kepentingan bangsa dan negara di atas kepentingan diri dan kelompoknya

11. Cinta tanah air, cara berpikir, berbuat yang menunjukkan kestiaan, kepedulian dan penghargaan yang tinggi terhadap bahasa, lingkungan , fisik, sosial, budaya ekonomi, politik bangsanya.

12. Menghargai prestasi, sikap dan tindakan yang mendorong dirinya untuk menghasilkan sesuatu yang berguna bagi masyarakat dan mengakui serta menghormati keberhasilan orang lain

13. Bersahabat/ komunikatif, tindakan yang memperlihatkan senang berbicara, bergaul dan kerjasama dengan orang lain

14. Cinta damai, sikap, perkataan dan tindakan yang menyebabkan orang lain merasa senang dan aman atas kehadirannya

15. Gemar membaca, kebiasaan menyediakan waktu untuk membaca berbagai bacaan yang memberikan kebajikan bagi dirinya sendiri.

16. Peduli lingkungan, sikap dan tindakan yang selalu berupaya untuk mencegah kerusakan pada lingkungan alam di sekitarnya dan mengembangkan upaya-upaya untuk memperbaiki kerusakan alam yang telah terjadi.

17. Peduli sosial, sikap dan tindakan yang selalu ingin memberi bantuan pada orang lain dan masyarakat yang membutuhkkan

18. Tanggung jawab, sikap dan perilaku seseorang untuk melaksanakan tugas dan kewajibannya, yang seharusnya dia lakukan terhadap diri sendiri, masyarakat, lingkungan(alam sosial dan budaya) negara dan tuhan Yang Maha Esa

Dalam artikel ini akan dibahas beberapa karakter sebagai pesan moral yang dapat disisipkan ke dalam topik/materi statistika. Dari 18 karakter yang telah disebutkan di atas, beberapa karakter yang akan dibahas dalam artikel ini berkaitan dengan topik dalam Statistika. Dimulai dari istilah yang tidak pernah terlewat saat pertemuan pertama mengenalkan statistika adalah populasi dan sampel. Melalui statistik, dapat diberikan gambaran informasi mengenai populasinya melalui sampel.

\section{Populasi dan Sampel Acak}




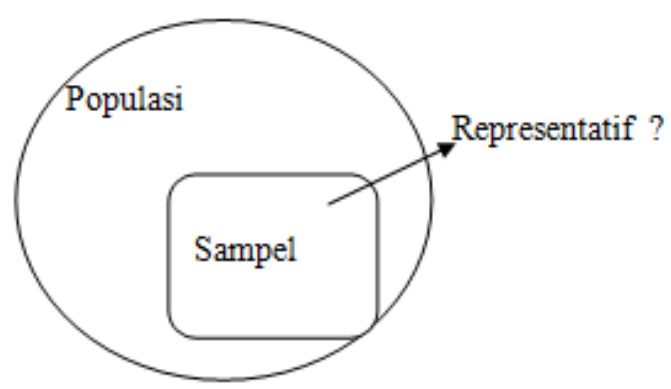

Gambar 1. Populasi dan Sampel

Pertanyaan yang dijumpai adalah apakah sampel sudah mewakili populasi (representatif), lalu bagaimana cara mengambil sampel yang representatif itu? apakah sampel acak solusinya?

Sampel acak adalah sampel yang diambil dengan secara acak dengan asumsi semua anggota populasi mempunyai kesempatan/peluang yang sama untuk terambil. Beberapa analisis dalam statistik mengasumsikan bahwa sampel harus acak dan independen. Lalu sebagian besar mahasiswa dengan penelitiannya menyatakan dengan cepat bahwa sampel yang diambilnya adalah sampel acak padahal belum tentu apa yang telah dilakukannya adalah benarbenar acak. Lalu bagaimana sebaiknya? Apakah perlu berbohong mengatakan sampel sudah diambil secara acak ?

Mahasiswa maupun pengguna statistik seperti peneliti perlu mempelajari tentang proses sampling. Berbagai macam sampling bisa dipelajari dan disesuaikan dengan kebutuhan ataupun keterbatasan peneliti. Dalam Sugiharto (2011), dijelaskan beberapa teknik sampling seperti judgement sampling, purposive sampling, expert sampling, stratified dan quoted sampling bisa menjadi salah satu cara sampling yang dapat dipilih. Peneliti harus benarbenar memahami populasi yang akan diteliti. Dalam hal ini tentu akan menghasilkan kesimpulan akhir yang harus dapat dipertanggungjawabkan, dan peneliti tidak berbohong dengan adanya sampel yang karena tidak serta merta menyatakan bahwa sampel acak. Peneliti mungkin bisa mengetahui konsekuensi adanya bias, kurang valid, atau kesimpulan yang tidak mungkin digeneralisir untuk seluruh populasinya.

Bagi mahasiswa jurusan ilmu murni seperti pada program studi matematika, matakuliah statistika merupakan salah satu matakuliah wajib. Tidak berbeda dengan program studi yang lain, Statistika juga merupakan materi yang penting karena berkaitan dengan alat/analisis dalam mengolah data penelitian. Tetapi ilmu statistika ini bukanlah hanya ilmu murni saja dan sering disebut dengan teoritis saja, karena ilmu ini menjadi sangat penting ditanamkan kepada mahasiswa untuk menyadari bahwa ilmu Statistika ataupun matematika erat kaitannya dengan penerapan pada bidang lain. Ilmu Statistika tidak berdiri sendiri tetapi bermanfaat bagi lingkungannya sekitarnya, seperti penerapan model statistika untuk menjawab penelitian pada berbagai bidang seperti pendidikan, sosial, ekonomi, keuangan, kesehatan, 
kedokteran, ataupun politik dan budaya dan lain sebgaainya. Mahasiswa perlu diberi penguatan sejak awal bahwa aktifitas membaca itu sangat penting, tidak cukup hanya satu referensi statistika saja tetapi harus ditambah dengan referensi lain untuk membantu memahami penerapan dan kegunaan belajar statistika.

Jika dikaitkan dengan budaya meneliti, menumbuhkan rasa ingin tahu, dan menjawab permasalahan maka hal ini kehidupan di sekitar bisa berhubungan erat dengan Statistika yang diterapkan di berbagai hal. Misalkan saja pada pemilu yang baru saja berlangsung 9 April 2014 yang lalu maka jauh hari sebelumnya, masyarakat dapat mengetahui secara cepat prediksi partai yang memiliki pemilih terbesar, atau perkembanganan respon masyarakat terhadap calon presiden. Untuk informasi tersebut seperti hasil survey atau quick count bukanlah

\begin{tabular}{|c|c|}
\hline 00000 & 0000 \\
\hline 12345678910 & 12345678910 \\
\hline Data I & Data II \\
\hline Mean $I=\frac{6+7+8+9+10}{5}=\frac{40}{5}=8$ & Mean II $=\frac{1+7+8+9+10}{5}=\frac{35}{5}=7$ \\
\hline
\end{tabular}

Gambar 2. Ilustrasi Data

Dengan memperhatikan kedua data diatas, tampak data sebelah kanan, data II memuat nilai 1 yang terletak jauh diantara kerumunan data yang lain sehingga datum 1 disebut outlier. Untuk data seperti ini yaitu data yang memuat outlier maka ukuran pemusatan data data populasi melainkan data sampel. Maka pada contoh ini, pengajar dapat menyisipkan karakter rasa ingin tahu tentang bagaimana proses dan pengambilan keputusan atau sebuah informasi dapat dijelaskan melalui statistika.

Selain populasi dan sampel, ukuran pemusatan data merupakan materi yang diberikan di awal pertemuan. Mean, median dan modus adalah tiga ukuran pemusatan data, dalam tulisan ini akan dibahas dua dianatranya yaitu mean dan median serta hubungannya dengan data outlier atau ekstrim.

\section{Mean - Median : Outlier}

Ukuran pemusatan yang sering digunakan adalah mean/rata-rata. Dalam hal ini rata-rata yang yang paling sering digunakan adalah arithmetic mean/ratarata hitung.

Berikut ini diberikan ilustrasi dua data 
mean terpengaruh ke bawah menjadi 7 pada data II. Apakah dapat dinyatakan valid seandainya beberapa siswa mengalami kejadian tertentu sehingga kemampuan saat mengerjakan tes tidak maksimal dan hasilnya tidaklah hampir sama dengan sekumpulan temantemannya yang lain ? mungkin ada yang berpendapat hasilnya menjadi kurang valid. Lalu bagaimana jika nilai 1 diabaikan saja karena dia outliers?

Keputusan untuk mengabaikan atau mempertahankan kasus outlier seharusnya didasarkan pada pemahaman tentang penyebab outlier dan hasil akhirnya. Jika outlier adalah kesalahan entri data atau kesalahan interpretasi oleh responden, mungkin harus dikeluarkan. Jika outlier adalah nilai yang tidak biasa tetapi sangat mungkin terjadi, maka sebaiknya dipertahankan. Langkah yang diambil bisa dengan melakukan analisis dua kali, satu dengan mempertahankan outlier termasuk dan satu lagi dengan mengabaikan outlier. Sehingga jika dilakukan dengan mengabaikan outliers akan diperoleh mean data II adalah

Mean II $*=\frac{7+8+9+10}{4}=\frac{34}{4}=8.5$

Nilai mean ini lebih besar dan menunjukkan keberhasilan kelas, tetapi jangan berbohong dengan statistik dengan mengabaikan nilai 1 . Untuk menunjukkan kemampuan yang sebenarnya dari kelas dengan outlier sangat disayangkan jika siswa dengan nilai 1 dihilangkan dalam proses mencari pemusatan data. Mungkin ada yang begitu saja menghilangkan untuk melaporkan bahwa kemampuan kelas sudah dapat dinyatakan cukup baik. Cara lain untuk menghilangkan yang dimaksud adalah dengan menggunakan trimmed mean, yaitu menghilangkan $5 \%$ data di bawah dan di atas. Dalam statistik, menyikapi adanya outliers haruslah hatihati, ketika data cenderung berditribusi miring (skewed) yaitu observasi cenderung terkonsentrasi di salah satu ujung nilai maka medianlah yang digunakan.

$$
\text { Median I }=8 \quad \text { Median II }=8
$$

Dengan menggunakan median, outliers diikutsertakan dalam proses pencarian nilai tengah yang tepat. Outliers tidak boleh langsung diabaikan tetapi dirangkul. Median adalah solusi yang lebih baik untuk melaporkan nilai tengah dari kelas tersebut. Ini yang menunjukkan median adalah ukuran pemusatan yang robust (kekar) terhadap outlier. Melalui median maka kemampuan terukur dari semua nilai yang ada sehingga outlier tidak begitu saja dihilangkan, tetapi hasil nilai yang dilaporkan merupakan nilai yang sesungguhnya tentang kecenderungan data terpusat. Dalam hal ini banyak pesan moral yang bisa disampaikan kepada mahasiswa, salah satunya karakter kejujuran terhadap data yang dimiliki. 
Outliers adalah data-data yang jauh dari sekumpulan data yang lain. Dengan mempertimbangkan sifat-sifat outliers, maka jika dianalogkan dengan kehidupan nyata seperti dalam kasus nilai hasil belajar siswa dalam suatu kelas diatas, maka outliers adalah siswa dengan nilai terendah atau jauh dibawah dibandingkan teman-temannya atau siswa yang memperoleh nilai paling tinggi atau jauh diatas dari sekumpulan temantemanya. Bisa jadi siswa yang mendapatkan nilai jauh di bawah dari sekumpulan teman-temannya perlu diperhatikan bukan diasingkan atau diabaikan. Demikian juga jika ada nilai yang jauh di atas sekumpulan maka bisa digali informasi bagaimana cara siswa tersebut mendapatkan nilai terbaik sehingga dapat menjadi informasi yang berguna untuk teman-temannya yang lain.

Sesuai dengan pernyataan mengenai pengembangan karakter subjek matematika dapat dilakukan dengan menyelaraskan nilai matematika material tersebut yang pada umumnya meliputi manfaat, keunikan, keindahan, netral, mandiri, originalitas, logika dan berpikir praktis (Marsigit, 2011). Outliers bisa jadi data yang unik dan bermanfaat jika dipelajari lebih lanjut. Maka pesan moral yang dapat disampaikan pada saat materi ukuran pemusatan data dan hubungannya dengan outliers adalah kepedulian terhadap sesama dan lingkungan.
Banyak manfaat yang akan diperoleh jika outlier diperhatikan, misalnya akan ditemukan masalah-masalah yang dihadapi beberapa siswa yang mendapatkan nilai jelek. Atau akan diperoleh tips terkait keberhasilan segelintir siswa yang nilainya sangat baik. Bagaimana kisah dan cara berpikir pengusaha yang sukses dipaparkan oleh Malcom Gladwell (2008) dalam buku Outliers yang dijelaskan secara singat oleh Mc. Callum, John, S. (2010). Kemungkinan perbedaan perspektif bisa membuat orang menemukan kesuksesannya sendiri. Orang-orang yang mempunyai pemikiran outliers (tidak seperti kebanyakan) bisa jadi akan menemukan kesuksesan dan hal ini bisa dipelajari oleh orang banyak untuk diambil sisi positifnya, misalnya strategistrategi yang bisa diaplikasikan dalam marketing untuk para pengusaha. Terkadang pemikiran pemikiran cemerlang adalah hasil pendapat yang out of box maksudnya keluar dari kebiasaan, tidak kaku dalam menghadapi suatu masalah. Oleh karenanya masih ada pesan lain yang disampaikan dari kasus yang memuat outliers, yaitu outliers bukan berarti dibuang atau disingkirkan tetapi ditelusuri untuk digali informasi yang berkaitan dengan mengapa bisa menjadi outliers.

Adakalanya ditemukan kasus beberapa mahasiswa yang menyendiri, kurang bergaul dengan yang lain, atau 
cenderung individualis sehingga jika ada problem pada salah satu mahasiswa, tidak ada teman-temannya yang mengetahui. Banyak kasus mengenai mahasiswa yang terjerat kasus depresi karena adanya masalah keluarga, tetapi cenderung introvert/tertutup sehingga tidak ada yang mendeteksi secara cepat, atau ada beberapa mahasiswa yang mempunyai kelemahan tertentu pada suatu materi dan malu bertanya kepada temannya atau pengajar. Untuk kasus-kasus ini mirip dengan outliers, mahasiswa dapat diingatkan kembali untuk bersahabat/ saling komunikatif dengan yang lain dalam belajar sehingga akan tercipta kebersamaan dalam perkuliahan, informasi yang berkembang mengenai problem yang dihadapi dalam suatu kelas bisa dicarikan solusi bersama.

\section{Kesimpulan}

Beberapa pesan moral seperti kejujuran, peduli dengan sesama dan lingkungan, bersahabat/ komunikatif, dan gemar membaca dapat disisipkan saat pemberian materi statistika. Melalui permasalahan yang dihadapi saat penelitian juga sifat, dampak dan manfaat dari suatu istilah dalam statistika pengajar dapat mengilustrasikan ke dalam kehidupan nyata, istilah-istilah tersebut diantaranya adalah populasi, sampel dalam penelitian, dan outliers. Manfaat yang diharapkan adalah mahasiswa tidak hanya mengetahui kegunaan dari suatu ukuran seperti median untuk mengatasi outliers, tetapi bagaimana menyikapi adanya outliers tersebut.

\section{Pustaka}

Endang Listyani. (2012). Implementasi Model Pembelajaran Matematika Dalam Pembentukan Karakter Peserta Didik. Prosiding Seminar Nasional Matematika dan Pendidikan Matematika.

Fleming, Michael C and Nellis, Joseph G. (2000). Principles of Applied Statistics. UK: Ligtning Source.

Kementrian Pendidikan Nasional, Badan Penelitian Dan Pengembangan Pusat Kurikulum. (2011). Pengembangan Pendidikan Budaya Dan Karakter Bangsa Pedoman Sekolah.

Marsigit. (2011). Pengembangan Karakter Dalam Pendidikan Matematika dalam Buku Pendidikan Karakter Dalam Perspektif Teori dan Praktik. Yogyakarta : UNY Press

Mc. Callum, John, S. (2010). Outliers: Malcolm Gladwell Does It Again. Sugiharto, dkk .(2003).Teknik Sampling. Jakarta : Gramedia 
